\title{
PREFACE
}

\section{Prescription for Health: Round 1 Initial Results}

\author{
Larry A. Green, MD
}

Prescription for Health, Denver, Colo

Ann Fam Med 2005;3(Suppl 2):S2-S3. DOI: 10.1370/afm.333.

$\mathrm{O}$ ur genetic endowment, social circumstances, environmental conditions, and health care are recognized to be important determinants of health, but our behavior is estimated to have a larger impact than any of these. Indeed, the choices we make about using tobacco and alcohol, physical activity, and diet are powerful, changeable contributors to suffering needlessly and dying prematurely. ${ }^{1,2}$

There is widespread acknowledgment that the health care that is delivered in the United States is not the health care that could and should be delivered. ${ }^{3,4}$ All primary care medical specialties have called for serious revisions in the delivery of primary care ${ }^{5-8}$ and the nation now enjoys the largest, best-trained primary care workforce in its history, comprised of nurses, physician assistants, general internists, general pediatricians, and family physicians. ${ }^{9}$ A medical home for everyone is envisioned that provides a reliable basket of services for people of all ages, regardless of their clinical concerns. ${ }^{10}$ Within this set of services are health assessment, disease prevention, health promotion, patient education, support for self-care, primary mental health care, advocacy for patients to get the services they need, and integration of services across the health care spectrum. ${ }^{5}$ These are the services necessary to promote and sustain healthy behaviors.

Meanwhile, the nation continues to spend more and more for health care services ${ }^{11}$ while failing to achieve top performance and falling behind other industrialized nations in terms of population health measures. ${ }^{12,13}$ For-

Conflict of interest: none reported

\section{CORRESPONDING AUTHOR}

Larry A. Green, MD

Director

Prescription for Health

Denver, CO

larry.green@uchsc.edu tunately there has been substantial progress in planning for redesigned health care, and there is keen ongoing interest in redesigning primary care practice for unprecedented performance..$^{10}$ Accompanying these developments in primary care and medicine, the science of behavior change has matured. ${ }^{14-16}$ To this mix has been added a new kind of research laboratory - the primary care practice-based research network (PBRN). ${ }^{17}$ Numerous local and regional as well as a few national networks now exist, having demonstrated their capacity to ask and answer important questions at medicine's front lines. ${ }^{18}$

Thus, a vibrant mix of opportunity, knowledge, resources, and challenge exists, inviting immediate action to insert into the "DNA" of new models of primary care effective services needed to enhance the health of the nation through the promotion of healthy behaviors by individuals. The Robert Wood Johnson Foundation, the Agency for Healthcare Research and Quality, and the nation's practice-based research networks united in a program named Prescription for Health ${ }^{19}$ to step up and make a difference. The basic idea is to move onto the largest single platform of health care delivery, the offices of primary care clinicians, ${ }^{20,21}$ to discover what it actually takes to help individuals make and sustain healthier choices.

This supplement verifies keen interest and responsiveness of frontline clinicians to this challenge and reports initial results from a first round of funding that enabled primary care clinicians in PBRN's to formulate and test some of their best, practical ideas about how to help people avoid and change unhealthy behaviors and adopt and maintain healthier choices. The central purpose of this first round of work was to demonstrate the feasibility of strategies in real primary care practices.

An overarching evaluation was embedded in Prescription for Health from its beginning, reaching into and across each network's strategies. With time, this evaluation, in collaboration with the networks, is making sense of innovations that enable lifestyle changes 
in primary care practice. Insights are emerging about what it takes, what conditions are necessary for achieving meaningful improvements, and promising practices discovered and employed by the networks.

Progress to date points toward necessary further work and the need for more comprehensive strategies, exactly the target of the next round of funding by Prescription for Health. This further work will push toward patient-oriented measures ${ }^{22}$ and comparisons of effectiveness across networks that may identify achievable options for widespread dissemination.

For those looking for ideal, proven strategies ready for immediate implementation in primary care practices, this supplement will prove disappointing. However, for those seeking evidence of feasibility of promising options for routine daily medical practice, this supplement is likely to be an encouraging resource. In addition to the insights and lessons compiled into this supplement, there are multiple other reports from the Prescription for Health practice-based research networks in press in various journals. By assembling this synopsis of experience from the first round of funding, it is hoped that further partnerships and efforts can be enabled to keep advancing toward the routine adoption into frontline primary care practices of strategies that work efficiently and are capable of enhancing the health status of the nation.

To read or post commentaries in response to this article, see it online at http://www.annfammed.org/cgi/content/full/3/Suppl_2/S2.

Key words: Practice-based research network; health behavior

Submitted April 8, 2005; accepted April 22, 2005.

Funding support: This work was supported by Prescription for Health, a national program of The Robert Wood Johnson Foundation with support from the Agency for Healthcare Research and Quality.

\section{References}

1. McGinnis JM, Foege WH. Actual causes of death in the United States. JAMA. 1993;270:2207-2212.

2. Mokdad AH, Marks JS, Stroup DF, and Gerberding JL. Actual causes of death in the United States, 2000. JAMA. 2004;291:1238-1245.

3. Institute of Medicine. Committee on Quality of Health Care in America. Crossing the Quality Chasm: A New Health System for the 21st Century. Washington DC: National Academy Press; 2001.

4. Geyman JP. Health Care in America. Can Our Ailing System Be Healed? Boston, Mass: Butterworth Heinemann; 2002.
5. Future of Family Medicine Project Leadership Committee. The future of family medicine: a collaborative project of the family medicine community. Ann Fam Med. 2004;2(supp 1):S3-S31.

6. Sandy LG, Schroeder SA. Primary care in a new era: disillusion and dissolution? Ann Intern Med. 2003;138:262-267.

7. Ludwig S. Academic general pediatrics: from endangered species to advanced scholars of general pediatrics: the report of a consensus conference. Ambul Pediatr. 2004;4:407-410.

8. Showstack J, Rothman AA, Hassmiller SB. The Future of Primary Care. San Francisco: Jossey-Bass, 2004.

9. The Robert Graham Center: Policy Studies in Family Medicine and Primary Care. The Physician Workforce of the United States. A Family Medicine Perspective. Washington, DC; 2004. Available at: http:// www.graham-center.org. Accessed April 8, 2005.

10. Spann SJ, for the members of Task Force 6 and the Executive Editorial Team. Task force report 6 . Report on financing the new model of family medicine. Ann Fam Med. 2004;2(suppl 3):S1-S21.

11. Smith C, Cowan C, Sensenig A, Catlin A, and the Health Accounts Team. Health spending growth slows in 2003. Health Affairs. 2005;24:185-194.

12. World Health Organization. The World health report, 2000. Health systems: Improving performance. Geneva: World Health Organization, 2000. Available at: http://www.who.int/whr/2000/en/. Accessed April 8, 2005.

13. Organisation for Economic Cooperation and Development. Health Data 2004. Available at: http://www.oecd.org.health/healthdata. Accessed April 8, 2005.

14. Pronk NP, Peek CJ, Goldstein MG. Addressing multiple behavioral risk factors in primary care. A synthesis of current knowledge and stakeholder dialogue sessions. Am J Prev Med. 2004;(2 suppl)4-17.

15. Glasgow RE, Goldstein MG, Ockene JK, Pronk NP. Translating what we have learned into practice. Principles and hypotheses for interventions addressing multiple behaviors in primary care. Am J Prev Med. 2004;(2 Suppl) 88-101.

16. Shumaker SA, Schron EB, Ockene JK, McBee WI. The Handbook of Health Behavior Change. 2nd ed. New York, NY: Springer; 1998.

17. Green LA, Miller RS, Reed FM, Iverson DC, Barley GE. How representative of typical practice are practice-based research networks? A report from ASPN. Arch Fam Med. 1993;2:939-949.

18. Green LA, Dovey SM. Practice-based primary care research networks. They work and are ready for full development and support. BMJ. 2001;322:567-568.

19. Prescription for health. Web site. Available at: http://www.prescriptionforhealth.org. Accessed April 8, 2005.

20. Ambulatory Health Care Data: National Ambulatory Medical Care Survey (NAMCS). Hyattsville, Md: National Center for Health Statistics. US Public Health Service; 2002. Available at: http://www.cdc. gov/nchs/about/major/ahcd/ahcd1.htm. Accessed April 9, 2005.

21. Green LA, Fryer GE, Yawn BP, Lanier D, Dovey SM. The ecology of medical care revisited. N Engl J Med. 2001;344:2021-2025.

22. Glasgow RE, Ory MG, Klesges LM, Cifuentes M, Fernald DH, Green LA. Practical and relevant self-report measures of patient health behaviors for primary care research. Ann Fam Med. 2005;3:73-81. 